\title{
Small States, Small Problems? Income, Growth, and Volatility in Small States
}

\author{
WILLIAM EASTERLY and AART KRAAY * \\ The World Bank, Washington, DC, USA
}

\begin{abstract}
Summary. - Small states have attracted a large amount of research. In this paper we test whether small states are any different from other states in terms of their income, growth, and volatility outcomes. We find that, controlling for location, small states have higher per capita GDP than other states. This income advantage is largely due to a productivity advantage, constituting evidence against the idea that small states suffer from an inability to exploit increasing returns to scale. Small states also do not have different per capita growth rates than other states. Small states do have greater volatility of annual growth rates, which is in part due to their greater volatility of terms of trade shocks. This terms of trade-based volatility is in turn due to small states' greater openness. Their greater openness on balance has, however, a positive net payoff for growth. The one differential policy measure that might be relevant for small states is to further open up to international capital markets in order to better diversify risk, but the benefits of even that are still unresolved in the literature. We conclude that small states are no different from large states, and so should receive the same policy advice that large states do. (C) 2000 Elsevier Science Ltd. All rights reserved.
\end{abstract}

Key words - The Caribbean, Pacific Islands, growth, volatility, trade, small states

Smallness is neither a necessary nor sufficient condition for slow economic development

T.N. Srinivasan (1986)

Economic storm clouds are gathering over paradise and the outlook is undeniably gloomy

A.J. Dolman (1985)

\section{INTRODUCTION}

Do small states suffer from their smallness? There are good theoretical reasons to believe that they do. The provision of public services may be subject to indivisibilities that lead to increasing returns to scale (Alesina \& Spoalare, 1997), especially fiscal institutions (Easterly \& Rebelo, 1993) and defense (Kuznets, 1960; Harden, 1985). Many theories of economic growth suggest increasing returns to scale in the private economy as well (Romer, 1986; Barro \& Sala-i-Martin, 1995; Aghion \& Howitt, 1998), which may be difficult to realize in small states. Small economies may also be at a disadvantage because their size prevents them from diversi- fying into a wide range of activities, making them more vulnerable to terms of trade shocks than large states (Commonwealth Consultative Group, 1997), Briguglio, 1995; Armstrong \& Read, 1998). Many small states suffer from poor location in that they are remote and/or landlocked, and many are located in regions prone to hurricanes and volcanic activity (Srinivasan, 1986). Public officials in small states may be much more likely to be subjected to conflicting pressures (Farrugia, 1993), and it may be difficult to recruit a high-quality civil service given the limited pool of candidates in small states (Streeten, 1993). The trend toward trade multilateralism may put small states at a disadvantage because they presently benefit

\footnotetext{
* The views expressed here are the authors' and do not reflect those of the World Bank, its Executive Directors, or the countries they represent. We would like to thank two anonymous referees, Edgardo Favaro, and seminar participants (especially our discussant Byron Blake) in the Joint Commonwealth Secretariat/World Bank Task Force Conference on Small States in St. Lucia in February 1999 for useful discussions. Final revision accepted: 7 February 2000.
} 
from many bilateral trade concessions (Armstrong \& Read, 1998).

These potential difficulties facing small states have not been lost on policymakers or academics. Numerous conferences and seminars on the special difficulties of small states have been convened over the past 40 years (Robinson, 1960; Benedict, 1967; Dobozi, Kellen, \& Matejka, 1982; Commonwealth Consultative Group, 1985, 1997; Small States Financial Forum, 1987, 1988; Kaminarides, Briguglio, \& Hoogendonk, 1989). International organizations such as the United Nations have commissioned studies on the problems confronting small states for many years (United Nations, 1971; Doumenge, 1983, UNCTAD, 1997) and the United Nations has formally recognized the special difficulties of small states in a resolution to that effect (Briguglio, 1995). Titles of papers on small states (see our bibliography) frequently feature ominous terms and phrases such as "Problems," "Vulnerability," "Small is Dangerous," and even (twice) "Paradise Lost." (Cashin \& Loayza, 1995.)

In this paper, we look for empirical evidence of alleged disadvantages of size by examining small states with population one million or less. If small size is a disadvantage, then these states must suffer with a vengeance. In particular, we would expect that small states must on average be less developed and grow less rapidly than larger states. We test this hypothesis using a large cross-country dataset including many small states. In light of the grim predictions of theory, the picture of small states which emerges from this analysis is somewhat surprising. After controlling for a range of factors, we find that small states have on average higher income and productivity levels than large states, and grow no more slowly than large states. Per capita GDP growth rates are more volatile in small states, due to their much greater exposure to international trade and fluctuations in their terms of trade. But, any growth disadvantages of this greater volatility are more than outweighed by the growth benefits of trade openness reaped by small states by virtue of their necessarily large trade volumes. Finally, small states are well positioned to take advantage of opportunities for international risk sharing, since the correlation of economic fluctuations in small states with the world business cycle is surprisingly low.

These results contribute evidence in support of the growing view in the literature that small size might not be a disadvantage after all.
Kuznets (1960) notes that small states also have advantages: primarily that many are lucky to have good natural resources and have a small and more cohesive populations which allows them to adapt better to change. Srinivasan (1986) and Streeten (1993) argue without systematic empirical evidence that small may also be beautiful. Using a sample of 48 countries Milner and Westaway (1993) fail to find evidence that the effect of a number of growth determinants varies with country size. Armstrong, de Kervenoael, Li and Read (1998) use cross-sectional regressions covering a large number of small states and independent regions to argue that population size does not significantly affect growth, controlling for initial income and regional effects.

The remainder of this paper proceeds as follows. In the next section we document that small states are richer and have higher productivity levels than large states. In Section 3 we observe that small states suffer no obvious growth rate disadvantage, and attribute this to a number of offsetting advantages and disadvantages of small states. In Section 4 we document that although terms of trade volatility contributes significantly to the greater volatility of growth in small states, this is not the whole story - a significant small state effect on volatility remains after we control for terms of trade variability. In Section 5 we note that small states are relatively well positioned to take advantage of opportunities to diversify away their special risks since they currently are not particularly financially open and the shocks they receive are relatively uncorrelated with those experienced by the rest of the world. Section 6 offers concluding remarks.

\section{SMALL STATES AND PER CAPITA INCOME LEVELS}

In this paper, we consider a large cross-section of 157 countries for which at least 10 years of annual data on per capita GDP adjusted for differences in purchasing power parity are available. Of these, 33 are small states defined as having an average population during 196095 of less than one million. These countries are listed in Table 1, and range in size from tiny St. Kitts and Nevis with population of 42,000 to Mauritius with 912,000. The income range is similarly wide, from very poor African countries such as Guineau-Bissau and Comoros with real PPP-adjusted per capita GDPs 
Table 1. Small states

\begin{tabular}{|c|c|c|c|}
\hline & & $\begin{array}{l}\text { Population } \\
\text { (Thousands) }\end{array}$ & $\begin{array}{c}\text { Average per capita } \\
\text { GEP, } 1985 \text { PPP- } \\
\text { adjusted dollars }\end{array}$ \\
\hline ATG & Antigua and Barbuda & 63 & 5329 \\
\hline BHR & Bahrain & 419 & 10342 \\
\hline BHS & Bahamas, The & 237 & 11136 \\
\hline BLZ & Belize & 178 & 3548 \\
\hline BMU & Barbados & 58 & 15356 \\
\hline $\mathrm{BRB}$ & Bermuda & 247 & 5341 \\
\hline BWA & Barbados & 880 & 1516 \\
\hline $\mathrm{COM}$ & Comoros & 340 & 632 \\
\hline CPV & Cape Verde & 295 & 746 \\
\hline CYP & Cyprus & 638 & 5084 \\
\hline DJI & Djibouti & 344 & 1479 \\
\hline FJI & Fiji & 602 & 3149 \\
\hline GAB & Gabon & 777 & 3853 \\
\hline GMB & Gambia, The & 628 & 803 \\
\hline GNB & Guinea-Bissau & 739 & 644 \\
\hline GRD & Grenada & 92 & 2632 \\
\hline GUY & Guyana & 719 & 1630 \\
\hline ISL & Iceland & 223 & 9689 \\
\hline KNA & St. Kitts and Nevis & 42 & 4399 \\
\hline LCA & St. Lucia & 148 & 3264 \\
\hline LUX & Luxembourg & 358 & 11934 \\
\hline MDV & Maldives & 201 & 1908 \\
\hline MLT & Malta & 341 & 4049 \\
\hline MUS & Mauritius & 916 & 4092 \\
\hline QAT & Qatar & 384 & 18278 \\
\hline REU & Reunion & 496 & 2253 \\
\hline SLB & Solomon Islands & 299 & 1845 \\
\hline SUR & Suriname & 378 & 2877 \\
\hline SWZ & Swaziland & 556 & 2358 \\
\hline SYC & Seychelles & 59 & 2214 \\
\hline VCT & St. Vincent and the Grenad & 107 & 3312 \\
\hline VUT & Vanuatu & 145 & 1633 \\
\hline WSM & Samoa & 160 & 1844 \\
\hline
\end{tabular}

around $\$ 600$ to wealthy oil-exporting countries such as Qatar with per capita GDP of over $\$ 18,000$. Although our sample is quite large, it is worth noting that it is not comprehensive but rather is constrained by data availability. Of the 212 states and territories listed in the World Bank's databases, 55 have populations less than one million, but we have only have internationally-comparable per capita GDP data for 33 of these small states. While it is not clear $a$ priori what biases this might introduce (both rich small states such as Liechtenstein and poor small states such as Equatorial Guinea are excluded from our sample), we do note that some caution is in order before generalizing our results to all small states. In subsequent regressions the sample is even smaller, reflecting the nonavailability of variables other than per capita incomes in these regressions. Details on variable definitions and data availability are provided in the Appendix A.

If small states suffer from the disadvantages of smallness, they should be poorer on average than larger states. What do we actually find? In Figure 1, we show that, without controlling for any other characteristic, small states have the same range of per capita incomes as the rest of the countries in the world. Moreover, if we control for the location by continent of all countries, whether they are oil producers, and whether they belong to the OECD, then small states are actually significantly richer than other states. We show this in the first column of Table 2, where we regress the logarithm of real per capita GDP at PPP on these dummy variables, as well as a dummy variable for small states. The significant coefficient on the small states dummy indicates that they are on 


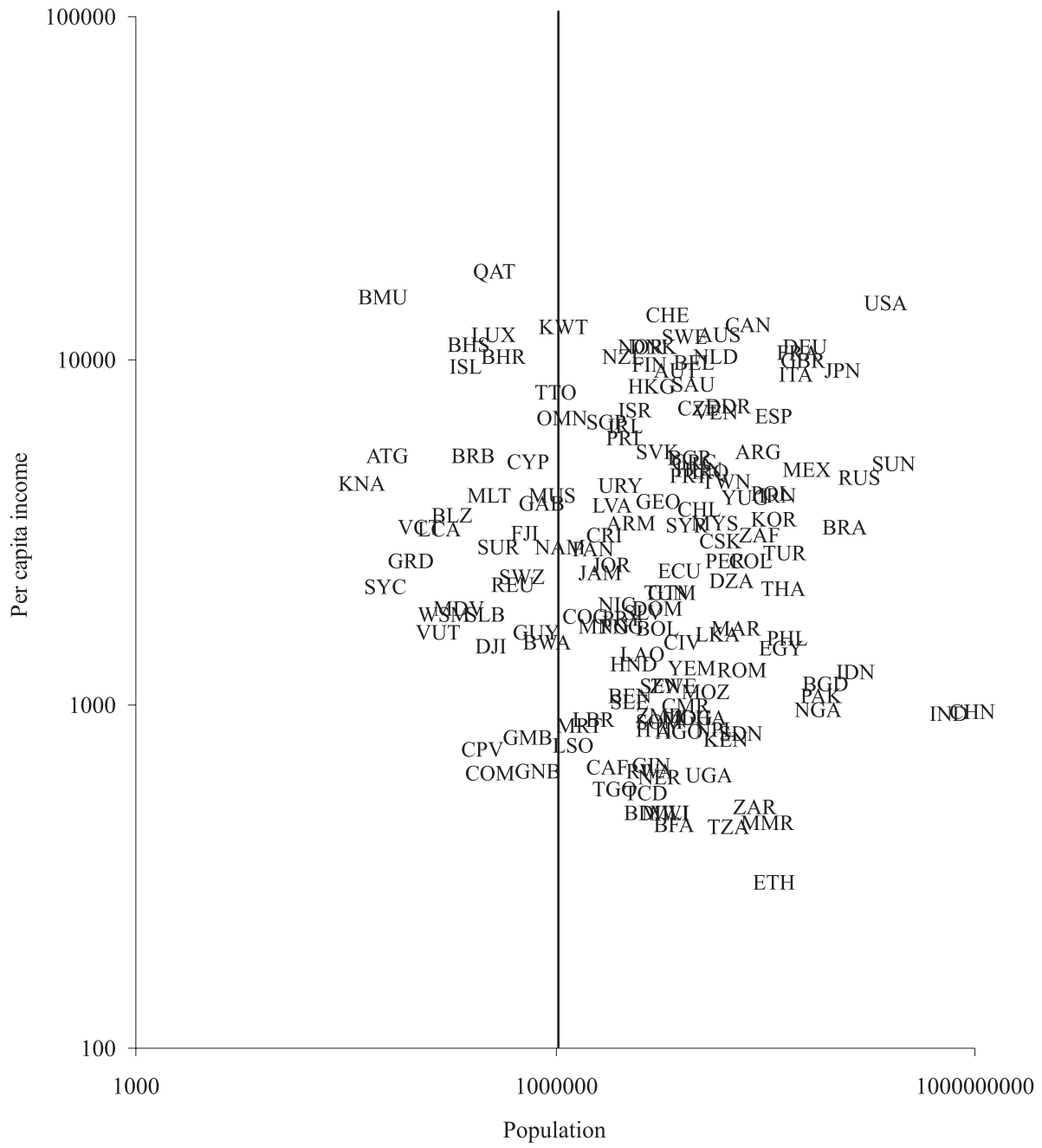

Figure 1. Per capita income and population size, averages 1960-95.

Table 2. Development advantages of small states ${ }^{\mathrm{a}}$

\begin{tabular}{lccc}
\hline Dependent variable & $\begin{array}{c}\text { Log real per capita } \\
\text { GDP, average } \\
1960-95\end{array}$ & $\begin{array}{c}\text { Under-5 infant } \\
\text { mortality per 1000 } \\
\text { live births }\end{array}$ & $\begin{array}{c}\text { Life expectancy at } \\
\text { birth, years }\end{array}$ \\
\hline OECD member & 1.169 & -28.415 & 7.736 \\
Oil exporter & $(0.148)$ & $(5.723)$ & $(1.018)$ \\
Small state & 0.815 & 0.896 & 0.893 \\
& $(0.178)$ & $(12.488)$ & $(1.513)$ \\
$R^{2}$ & 0.403 & -22.887 & $(1.383)$ \\
Number of observations & $(0.108)$ & $(9.548)$ & 0.719 \\
\hline
\end{tabular}

${ }^{a}$ Note: All regressions include a full set of regional dummies (sub-Saharan Africa, Asia, Europe and Central Asia, Middle East and North Africa, and the Americas). Standard errors are White-corrected for heteroskedasticity. 
average $50 \%(=\exp (0.403)-1)$ richer than their regional neighbours. We note that this result does not reflect the obvious outliers in the sample, since the oil exporting countries Qatar and Bahrain are picked up by the oil exporter dummy, and Luxembourg and Iceland are picked up by the OECD member dummy. Even if we exclude two other particularly wealthy small states not captured by these dummy variables (Bermuda and Bahamas), we still find that small states are nearly $40 \%$ richer than other states.

These results do not appear to be sensitive to the population threshold at which we divide countries into small and large states. Figure 2 plots the residuals from this regression (excluding the small states variable) by quintile of population, and we see the very strong income effect in the bottom two population quintiles. ${ }^{1}$ We also note that the favorable performance of small states carries over to other quality of life indicators. For example, if we in turn use under-five infant mortality and life expectancy at birth as the dependent variable in the above regression, we find that infant mortality is significantly lower in small states by 22 per thousand, while life expectancy is about four years higher (columns 2 and 3 of Table 2). Although this analysis does not tell us why small states are so much richer than their

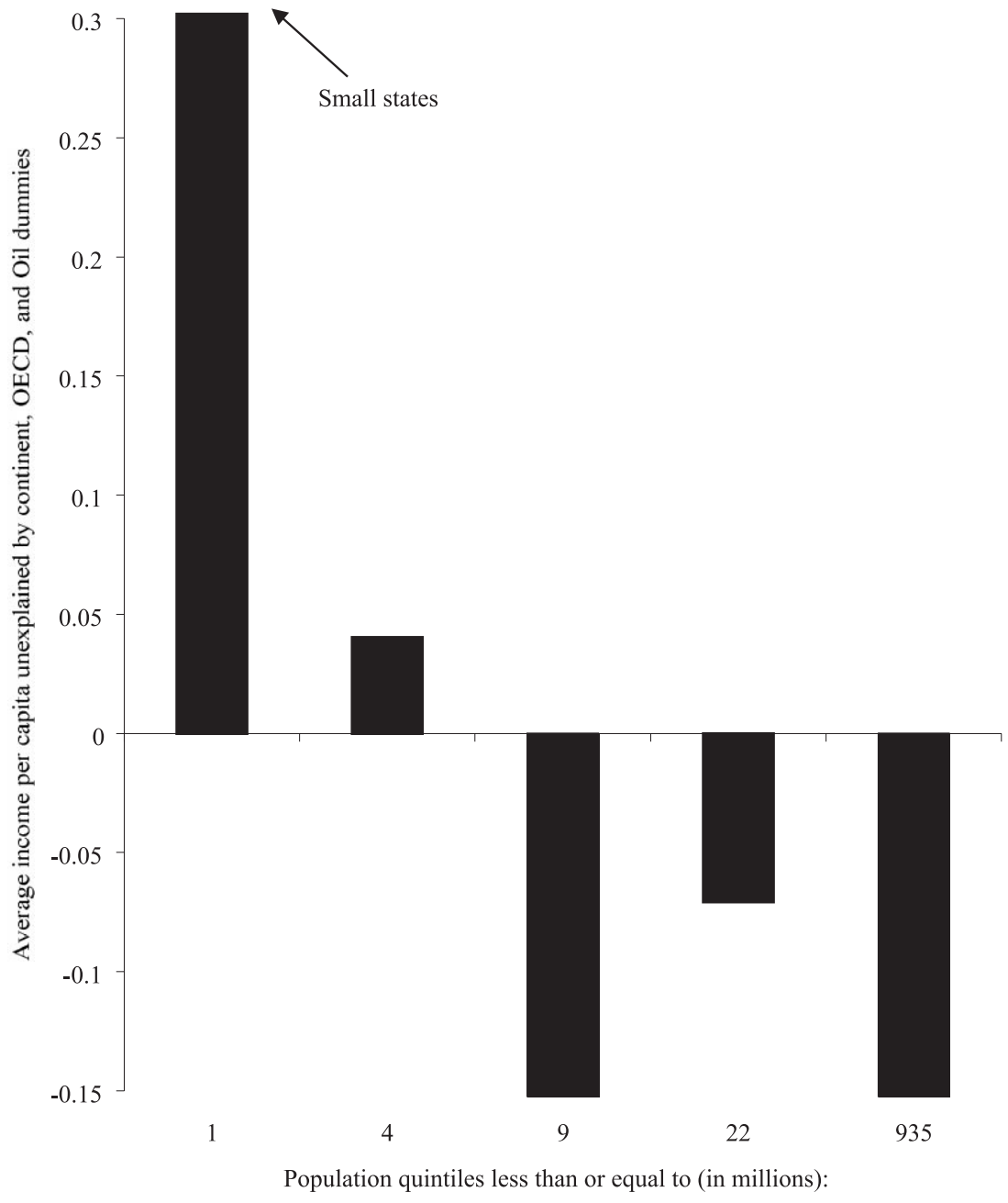

Figure 2. Unexplained income level and population size. 
regional neighbors and have better human development indicators, it does cast doubt on the often-heard arguments that small states suffer from a development disadvantage.

We next ask whether small states are richer than large states because they save more or because they have higher productivity levels. Following Mankiw, Romer and Weil (1992), we consider the prediction of the neoclassical Solow growth model that the steady-state level of output per person is given by:

$Y / L=A(s /(x+\delta+n))^{\alpha /(1-\alpha)}$,

where $Y / L$ is output per person, $A$ is the level of labor-augmenting productivity, $s$ the investment to GDP ratio, $x$ the rate of laboraugmenting productivity growth, $\delta$ the depreciation, $n$ the population growth, and $\alpha$ is the share of capital income in GDP. We assume a productivity growth of $2 \%$ and a depreciation rate of $7 \%$. We take logs of both sides and regress the log of output per person on the same dummies as above (capturing continental and other productivity differences) and the log of the second multiplicative term in (1):

$$
\begin{aligned}
\ln (Y / L)= & \ln A+\alpha /(1-\alpha) \\
& \times[\ln s-\ln (x+\delta+n)] .
\end{aligned}
$$

We call this second term MRW, and report the results of this specification in the first column of Table 3. Comparing the coefficient on the small states dummy with that in the first column of Table 2, we find that small states' productivity advantage accounts for about two-thirds of their income per capita advantage (i.e. 0.267/ 0.403). This evidence is inconsistent with the commonly-held idea that small states suffer from productivity disadvantages due to their inability to exploit increasing returns to scale. We also note that our specification differs from Mankiw et al. (1992) in that we allow the average level of productivity to vary across regions, and these differences are statistically significant (remember that the regressions include a full set of regional dummies). Once we allow the productivity level to vary, the coefficient on MRW implies a capital share of 0.28 which is in line with most estimates from national income accounting.

It is interesting to decompose the MRW into its numerator and denominator from Eqn. (1). We do this in the second and third columns of Table 3, where we regress the log investment rate and the population growth rate on the same set of dummy variables as before. We find that that small states have significantly higher investment rates but not significantly lower population growth rates. This suggests that some portion of the previously-unexplained income differential between small states and large states can be explained by the former's higher investment rates.

We conclude with two important caveats regarding these results on the productivity and investment advantages of small states. First, the regressions in Table 3 do not control for differences across countries in human capital, since it is difficult to adequately measure saving in the form of human capital. As a result, the productivity advantage of small states to some extent reflects their human capital differences from the rest of the world. This is consistent with the strand of the literature that argues that small states need to rely on imported technology and high quality human capital to compensate for their lack of natural resources. Briguglio (1995) suggests the importance of regional technical cooperation; Milner and Westaway (1993) find that small states have a weak disadvantage in agricultural technological catch-up but a weak advantage in non-agricultural technological catch-up; and Armstrong and Read (1998) suggest that advances in transport and communications technology have helped offset "smallness" and "remoteness").

Second, we should take with more than a grain of salt the result that investment accounts for some of the income advantage of small states. The significance of the MRW term in Table 3 may reflect reverse causality-richer states can afford to invest more and are usually thought to choose lower population growth than poor states. Or it may reflect an omitted third factor, like incentive policies that affect both investment and income. It is difficult to control adequately for these possibilities. Instead, we simply note that they are likely to result in an overstatement of the contribution of investment to the income advantage of small states.

\section{MICRO STATES AND MACRO GROWTH}

Even if small states do not have a disadvantage in terms of their income levels, they might grow more slowly over time for various reasons. Several endogenous growth theories 
Table 3. Productivity advantages of small states ${ }^{\mathrm{a}}$

\begin{tabular}{lccc}
\hline Dependent variable & $\begin{array}{c}\text { Log real per capita } \\
\text { GDP, average 1960-95 }\end{array}$ & $\begin{array}{c}\text { Log investment as a } \\
\text { share of GDP }\end{array}$ & $\begin{array}{c}\text { Average annual popu- } \\
\text { lation growth, 1960-95 }\end{array}$ \\
\hline OECD member & 1.122 & 0.199 & -0.411 \\
& $(0.114)$ & $(0.098)$ & $(0.129)$ \\
Oil exporter & 0.692 & 0.138 & $(0.166$ \\
Small state & $(0.151)$ & $(0.160)$ & -0.241 \\
MRW & 0.267 & 0.381 & $(0.146)$ \\
$R^{2}$ & $(0.132)$ & $(0.107)$ & 0.701 \\
Number of & 0.389 & & 139 \\
observations & $(0.102)$ & 0.440 & 139 \\
\hline
\end{tabular}

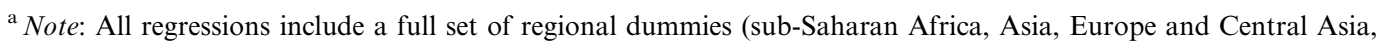
Middle East and North Africa, and the Americas). Standard errors are White-corrected for heteroskedasticity.

predict that growth rates will be positively correlated with size due to scale effects. As we discuss below, small states exhibit greater output volatility, which has been shown empirically to have adverse effects on growth (Ramey \& Ramey, 1995). What do the data say? In Figure 3 we show that small states have the same range of growth experiences as other

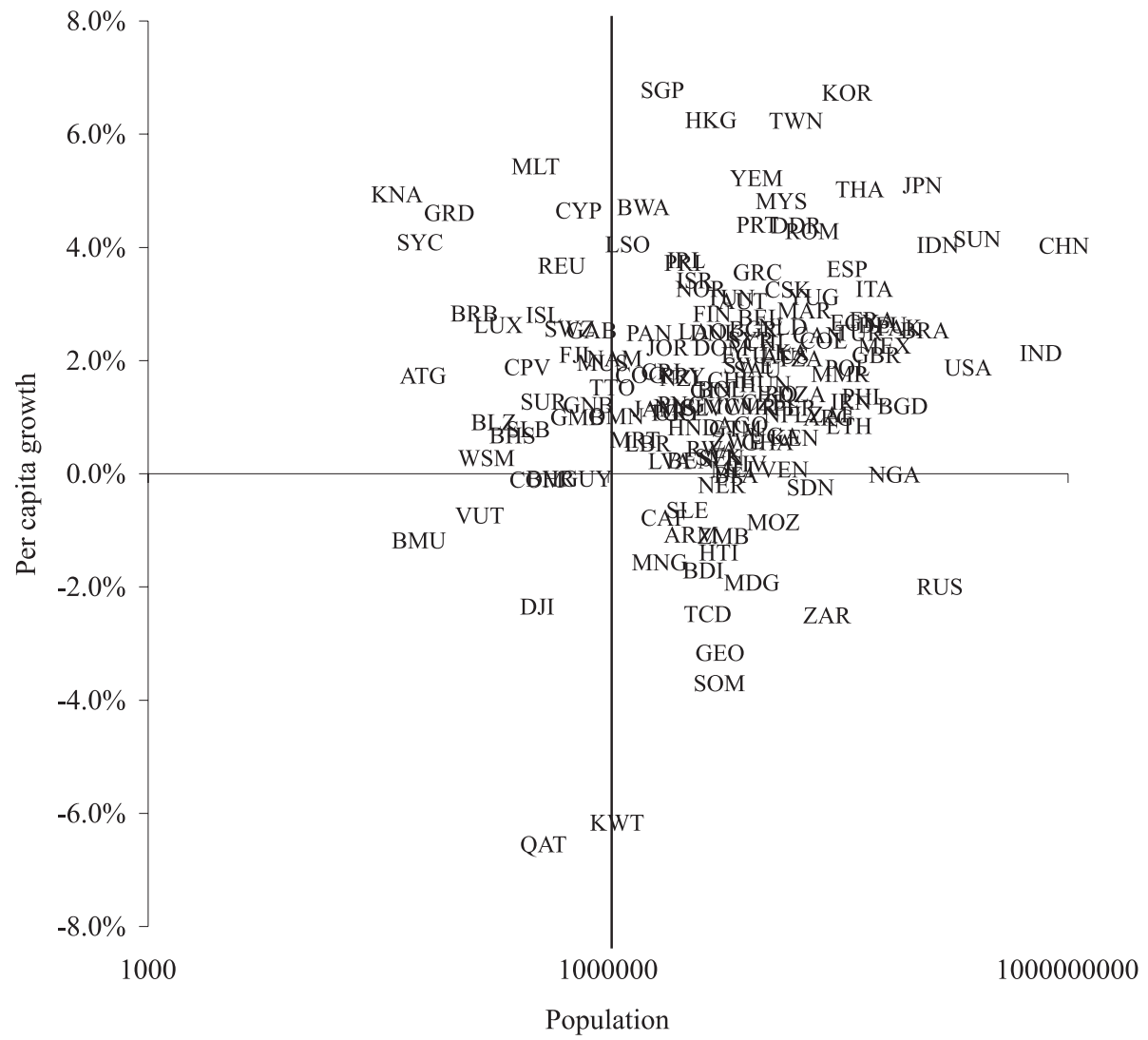

Figure 3. Average per capita growth and population size 1960-95. 
states, suggesting that there is no obvious scale effect for growth rates that is related to population size. There is also no growth difference for small states after controlling for continental location, oil, and OECD dummies, as shown in the first column of Table 4 where we regress growth on these dummies and the small states dummy.

Why do small states not suffer any apparent growth disadvantages due to their small size? To answer this question, we consider a parsimonious cross-country growth regression which captures two of the factors prominent in the small states debate: openness to international trade (measured as the share of imports and exports in GDP), and volatility (measured as the standard deviation of annual growth rates within each country). We also include initial income to capture convergence effects, and secondary school enrollment rates. The results are shown in the second column of Table 4. All of the variables are significant with the expected sign. The negative coefficient on initial income shows that there is conditional convergence, secondary enrollment rates and trade openness are positively correlated with growth, and growth rate volatility has a negative effect on growth.

This regression framework provides some useful clues as to why the small state dummy is not significant in the basic regression in the first column of Table 4. In particular, we can see from this regression that small states will have several offsetting advantages and disadvan- tages. We have already seen that they are richer than other countries (relative to regional averages) and hence will have slower growth than average by the conditional convergence effect. They have slightly higher secondary enrollment rates, which would give them higher growth. Most important, as we document below, small states tend to have much higher trade shares (which is good for growth), offset by much higher volatility of growth rates (which is bad for growth). ${ }^{2}$ As a result, the insignificance of the small state dummy in the growth regression suggests that the negative effects of high initial income and high volatility are roughly offset by the positive effects of trade openness and better educational attainment.

In order to document the magnitude of these offsetting effects, we first need to know how different small states are from nonsmall states in terms of their growth determinants. We document the well-known fact that small states typically have much higher trade ratios than larger states in the first column of Table 5, where we regress this variable on the same set of dummy variables as before, as well as the small states dummy. The consequences for openness of being a small state are truly remarkable. Small states have a ratio of trade to GDP that is 54 percentage points (1.2 standard deviations) higher than the average economy controlling for continent dummies! Second, real per capita GDP growth rates tend to be much more volatile in small states. The second column of Table 5 shows that the

Table 4. Growth in small states ${ }^{\mathrm{a}}$

\begin{tabular}{lcc}
\hline Dependent variable & $\begin{array}{c}\text { Average annual real per capita } \\
\text { GDP growth 1960-95 }\end{array}$ & $\begin{array}{c}\text { Average annual real per capita } \\
\text { GDP growth 1960-95 }\end{array}$ \\
\hline OECD member & 0.007 & 0.009 \\
& $(0.004)$ & $(0.006)$ \\
Oil exporter & -0.014 & $(0.0004)$ \\
& $(0.007)$ & -0.017 \\
Small state & 0.002 & $(0.004)$ \\
& $(0.005)$ & 0.0003 \\
Log of real per capita GDP in & & $(0.0001)$ \\
first available year & & 0.012 \\
Average secondary school & & $(0.003)$ \\
enrollment rate, 1960-95 & & -0.179 \\
Average share of trade in GDP, & & $(0.082)$ \\
1960-95 & & 0.535 \\
Standard deviation of annual & 0.195 & 130 \\
GDP growth, 1960-95 & 154 & 0 \\
$R^{2}$ & & \\
Number of observations & & \\
\hline
\end{tabular}

${ }^{a}$ Note: All regressions include a full set of regional dummies (sub-Saharan Africa, Asia, Europe and Central Asia, Middle East and North Africa, and the Americas). Standard errors are White-corrected for heteroskedasticity. 
Table 5. Growth advantages and disadvantages of small states ${ }^{\mathrm{a}}$

\begin{tabular}{lccc}
\hline Dependent variable & $\begin{array}{c}\text { Share of trade in } \\
\text { GDP, average } \\
1960-95\end{array}$ & $\begin{array}{c}\text { Standard deviation of } \\
\text { annual GDP growth, } \\
1960-95\end{array}$ & $\begin{array}{c}\text { Secondary school } \\
\text { enrollment rate average } \\
1960-95, \text { percent }\end{array}$ \\
\hline OECD member & -0.179 & -0.026 & 27.705 \\
& $(0.078)$ & $(0.004)$ & $(5.844)$ \\
Oil exporter & 0.145 & 0.016 & 6.587 \\
& $(0.095)$ & $(0.005)$ & $(5.821)$ \\
Small state & 0.539 & 0.014 & 8.344 \\
& $(0.071)$ & $(0.003)$ & $(4.440)$ \\
$R^{2}$ & 0.286 & 0.468 & 0.717 \\
Number of observations & 158 & 154 & 136 \\
\hline
\end{tabular}

${ }^{a}$ Note: All regressions include a full set of regional dummies (sub-Saharan Africa, Asia, Europe and Central Asia, Middle East and North Africa, and the Americas). Standard errors are White-corrected for heteroskedasticity.

standard deviation of annual real per capita GDP growth is 1.4 percentage points higher in small states than in nonsmall states. ${ }^{3}$ Finally for completeness we show that while secondary school enrollment rates are modestly higher in small states, this difference is only marginally statistically significant.

These results suggest that the absence of a clear growth advantage of small states is due to three main offsetting effects: (a) they are significantly richer, and hence grow more slowly due to the conditional convergence effect; (b) they are significantly more open to international trade, which is good for growth, and (c) they suffer from significantly greater growth rate volatility, which is bad for growth. Interestingly, the positive growth effect of openness in Table $5(0.012 \times 0.54=0.65 \%)$ is 2.5 times larger than the negative growth effect $(-1.79 \times 0.014=-0.25 \%)$ of small states' greater output volatility. This suggests that even if output volatility is one of the consequences of openness (as we discuss in more detail below), small states' greater openness is still on balance a positive factor for small states' growth. This finding is of particular interest, given the widely held view that small states suffer from their openness. ${ }^{4}$ Of course, any source of growth volatility that is not related to openness might still be detrimental to small states' growth performance.

Finally, it is interesting to note that one often-heard benefit of small states does not appear to be empirically very important. It is often argued that one of the advantages of small states is that they tend to be ethnically very homogeneous, which may make it easier for such states to forge the political consensus required to adjust to a changing environment (for example, Kuznets, 1960). Easterly and
Levine (1997) and Alesina, Baqir and Easterly (1999) find that measures of ethnic fractionalization are associated with a lower level of public goods provision and lower growth. But, the mean value of an ethnolinguistic indicator of diversity among those small states for which data are available is insignificantly different from that among nonsmall states, suggesting that the benefits of homogeneity may not be especially pronounced for small states. 5

\section{OPENNESS AND VOLATILITY}

In the previous section we saw that small states reap growth benefits from their openness to international trade, but suffer growth costs due to the greater volatility of their growth rates. In this section we consider in more detail the relationship between trade openness and volatility in small states. A significant portion of the growth rate volatility experienced by small states can be attributed to volatility in their terms of trade, but this is not the entire story. Even after controlling for terms of trade volatility, growth rates in small states are significantly more volatile than in nonsmall states.

We first document that the volatility of terms of trade shocks experienced by small states is much greater than for larger states. We define terms of trade shocks as the growth in the local currency price of exports times the share of exports in GDP less the growth in the local currency price of imports less the share of imports in GDP, which captures both the magnitude of price fluctuations (changes in export and import prices) and their importance for the domestic economy (weighted by the shares of exports and imports in GDP). We 
then regress the standard deviation of this measure of terms of trade shocks on the same set of regional dummies as before, dummy variables to capture oil exporters and commodity exporters who are more likely to suffer extreme fluctuations in their terms of trade, and the small state dummy. The results are shown in the first column of Table 6 . We find that there is a highly significant small state effect, with the standard deviation of terms of trade shocks larger by 0.013 (or about onethird of one standard deviation of the dependent variable) in small states.

This terms of trade volatility might be due to two factors. First, we have already seen that the share of trade in GDP is especially large in small states, and this may contribute to the magnitude of our measure of terms of trade shocks (since it weights changes in import and export prices by the shares of imports and exports in GDP). Second, small states' exports are likely to be more specialized than those of large states, both in terms of products exported and in terms of export markets (Kuznets, 1960; Armstrong \& Read, 1998). As a result, the average prices of their exports and imports might be more volatile than in countries with more diversified trade patterns. The distinction between these two factors is important because there is little that small states can do about their overall trade volumes - autarky is simply not an option for small states that produce a much narrower range of goods and services than they consume, and moreover we have already documented the substantial growth benefits accruing to small states due to their openness. If in contrast the greater volatility of growth is due to excessive reliance on a few export products and a few export markets, then policies designed to help diversify exports may help to dampen economic fluctuations. ${ }^{6}$

We can get a rough idea of the relative importance of these two factors by redefining the terms of trade shock as the unweighted difference between the growth in export prices and the growth in import prices. When we use this alternative measure of terms of trade shocks as the dependent variable in the second column of Table 6 , we find that the small states dummy is negative and insignificant. That is, the volatility of changes in the price of exports relative to imports is if anything lower in small states relative to larger states. Although this is not conclusive evidence, it does cast doubt on the notion that small states are especially vulnerable to external shocks simply because their international trade is more specialized. Rather, the greater volatility of terms of trade shocks in small states is primarily due to their unavoidably large trade shares.

Finally, it is worth noting that greater volatility of growth in small states is not solely due to their greater susceptibility to terms of trade shocks. To illustrate this point, we re-estimate the growth rate volatility regression in the second column of Table 4, adding the volatility of the terms of trade as an explanatory variable. The results are shown in the last column of Table 6 . We find that the small state dummy remains significant even after controlling for the effect of greater terms of trade volatility on the volatility of overall growth. This indicates that a significant portion of the volatility of output in small states is unrelated to their

Table 6. Volatility in small states ${ }^{\mathrm{a}}$

\begin{tabular}{lccc}
\hline Dependent variable & $\begin{array}{c}\text { Standard deviation of } \\
\text { annual terms of trade } \\
\text { growth, 1960-95 }\end{array}$ & $\begin{array}{c}\text { Standard deviation of } \\
\text { unweighted annual } \\
\text { terms of trade growth, } \\
1960-95\end{array}$ & $\begin{array}{c}\text { Standard deviation of } \\
\text { annual per capita real } \\
\text { GDP growth, 1960-95 }\end{array}$ \\
\hline Commodity exporter & 0.007 & 0.023 & 0.007 \\
Oil exporter & $(0.005)$ & $(0.013)$ & $(0.004)$ \\
& 0.023 & 0.074 & 0.012 \\
Small state & $(0.005)$ & $(0.024)$ & $(0.006)$ \\
Terms of trade & 0.013 & -0.011 & $(0.021$ \\
Volatility & $(0.005)$ & $(0.011)$ & 0.250 \\
$R^{2}$ & & & $(0.105)$ \\
Number of & 0.490 & 0.474 & 0.535 \\
observations & 114 & 114 & 114 \\
\hline
\end{tabular}

${ }^{a}$ Note: All regressions include a full set of regional dummies (sub-Saharan Africa, Asia, Europe and Central Asia, Middle East and North Africa, and the Americas). Standard errors are White-corrected for heteroskedasticity. 
exposure to international trade. This additional volatility may be due to several factors. Many of the small states in our sample are located in areas prone to natural disasters such as hurricanes, and the higher growth volatility in small states may simply reflect the devastating effect of these natural forces. It is also possible, however, that some of this observed volatility reflects difficulties in measuring per capita incomes, which may be particularly acute in small states where statistical institutions may be weaker than average.

\section{OPPORTUNITIES FOR DIVERSIFICATION}

In the previous section we have seen that small states experience much more volatile growth rates than nonsmall states. This in part reflects their greater vulnerability to terms of trade shocks, and perhaps also the tendency of many small states to suffer heavily from natural disasters. In this section we briefly consider the potential of small states to mitigate the adverse effects of this largely unavoidable volatility by sharing risks with the rest of the world.

One of the potential benefits of financial openness is that it allows countries to share risks with the rest of the world, by holding claims on assets located outside their borders whose returns are not perfectly correlated with returns to domestic assets. The magnitude of these benefits depends on how volatile are shocks to the domestic economy, and the extent to which they are uncorrelated with shocks abroad. Small states are particularly well situated to benefit from such risk sharing arrangements, for two reasons. First, small states suffer large shocks, as documented in Section 4. Second, in contrast to the often-heard view that small states are particularly susceptible to cyclical fluctuations abroad, we find that the shocks experienced by small states are not unusually correlated with the world business cycle. We illustrate this point in the first column of Table 7, where we regresses the correlation of per capita GDP growth in a country with OECD average real per capita GDP growth on the same set of dummies as before, as well as the logarithm of average per capita GDP (to capture the stylized fact documented by Kraay and Ventura (1998) that business cycles in poorer countries tend to be less correlated with the world average cycle), and a small state dummy. The small state dummy is insignificant, suggesting that small states are in fact not unusually correlated with the OECD cycle. It is important to note, however, that growth rates in neighboring small states may be highly correlated, especially to the extent that their growth rate volatility reflects natural disasters such as hurricanes. This suggests that regional arrangements to share risk among small states will be much less valuable than pooling risks with a wider range of countries.

Despite the potential benefits of risk sharing through participation in international financial

Table 7. Risk sharing in small states ${ }^{\mathrm{a}}$

\begin{tabular}{lccc}
\hline Dependent variable & $\begin{array}{c}\text { Correlation of real per } \\
\text { capita GDP growth } \\
\text { with OECD average } \\
\text { real per capita GDP } \\
\text { growth, 1960-95 }\end{array}$ & $\begin{array}{c}\text { Fraction of years over } \\
\text { 1960-95 during which } \\
\text { capital controls were in } \\
\text { place }\end{array}$ & $\begin{array}{c}\text { Average capital inflows } \\
\text { plus capital outflows as } \\
\text { a fraction of GDP, } \\
1960-95\end{array}$ \\
\hline OECD member & 0.082 & -0.149 & 0.016 \\
Oil exporter & $(0.069)$ & $(0.100)$ & $(0.029)$ \\
Small state & -0.077 & -0.097 & -0.027 \\
& $(0.065)$ & $(0.116)$ & $(0.016)$ \\
Log real GDP per & 0.013 & 0.026 & 0.027 \\
capita, average 1960-95 & $(0.054)$ & $(0.080)$ & $(0.013)$ \\
Commodity exporter & 0.119 & -0.170 & 0.024 \\
$R^{2}$ & $(0.029)$ & $(0.050)$ & $(0.013)$ \\
Number of & 0.026 & $(0.063)$ & -0.014 \\
observations & $(0.058)$ & 0.278 & $(0.011)$ \\
\hline
\end{tabular}

${ }^{a}$ Note: All regressions include a full set of regional dummies (sub-Saharan Africa, Asia, Europe and Central Asia, Middle East and North Africa, and the Americas). Standard errors are White-corrected for heteroskedasticity. 
markets, small states do not appear to be especially open financially. We illustrate this point in the last two columns of Table 7, where we regress two alternative measures of financial openess on a set of regional dummies as well as the logarithm of average per capita income. The first is the fraction of years for which data are available in which the IMF reports restrictions on capital account transactions in that country. The coefficient on the small state dummy is positive, although insignificantly so. ${ }^{7}$ This suggests that small states are not particularly open to financial flows, as measured by legal impediments to such flows. Combining this observation with the empirical results of Lewis (1996), who finds that consumption risks are less diversified in countries with this measure of capital controls, this suggests that small states are not taking full advantage of the opportunities for risk diversification afforded by international capital markets. The second outcome measure of financial openness (capital inflows plus capital outflows as a share of GDP) paints a somewhat more favorable picture, as the small state dummy is positive and statistically significant at conventional levels. This suggests that the volume of capital flows is slightly larger for small states than for nonsmall states, although the magnitude of this effect is small-only about 2-3 percentage points of GDP. Overall, this evidence suggests that small states are not as financially open as they might be given the high volatility they face, and hence are not fully exploiting opportunities for international risk diversification.

We conclude this section with the observation that although greater financial openness may help small states insure against the large shocks they receive, financial openness is itself no panacea. Grilli and Milesi-Ferretti (1995) and Rodrik (1998) both note that there is no evidence that financially-open economies grow faster or enjoy higher investment rates. On the other hand, there is also no systematic evidence in favor of the popular view that by opening up financially, countries expose themselves to greater volatility due to the vagaries of international financial markets (Kraay, 1998). In summary, although financial openness may provide a valuable means for small states to diversify some of the large risks they face, existing evidence does not support the view that there will be a large growth payoff from such policies.

\section{CONCLUSIONS}

Our analysis suggests that small states have perhaps received excessive attention from the literature - notwithstanding our own addition to the literature! - as special cases calling for special policy measures. We find that small states have, if anything, significantly higher per capita income than others in their region. There is no significant difference in growth performance between large and small states. It is true that growth volatility and volatility of terms of trade shocks as percentage of GDP is higher in small states, but this is largely due to their greater trade openness - and the net benefits of openness on growth are positive. The one missing piece in the current situation of small states is that they are not fully exploiting the potential to diversify their risks by opening up to international capital movements. But even the payoff to filling in this last missing piece is unclear from evidence in the literature.

This is not to say that small states are free of economic problems! Many small states are still poor, and promoting growth as a means to alleviate poverty is as important in small poor states as it is in other poor countries. The good news is that the lessons of growth experience from all countries seem to be applicable to small states, so they can benefit from the large amount of crosscountry evidence on the determinants of long-run growth.

\section{NOTES}

1. All of the results reported in the paper are qualitatively similar if we use the logarithm of population rather than an indicator variable for small states.

2. The model of Alesina and Spolaore (1997) mentioned earlier has the prediction that openness reduces the costs of forming small states, since countries will not need to produce domestically the entire basket of goods they wish to consume.

3. An interesting historical footnote is that the greater volatility of small states has not always been accepted. Tarshis (1960) finds little evidence of a relationship between the coefficient of variation of per capita 
income and size across US states, and poses this as a puzzle.

4. This view of small states dates back at least to Scitovsky (1960). Dolman (1985) goes so far as to suggest that many small island states would be better off reverting to autarkic subsistence economies.

5. One characteristic of small states that we do not examine is geographical isolation. It is difficult to test the effect of this, because some of the literature indicates that being geographically isolated because you are landlocked is harmful to growth, while other strands of the literature stress "islandness." Since virtually all small states are either islands or landlocked, it would be hard to separate out the effects of geographical isolation, however measured.

6. Of course, to the extent that scale economies are important at the industry level, the potential for such diversification might be limited in small states.

7. As reported in the IMF's Annual Report on Exchange Arrangements and Exchange Restrictions (IMF, various issues). The disadvantages of this measure are well-known. First, it captures only the presence, and not the intensity of controls. Second, it captures only controls on residents, and not on nonresidents, although there is some presumption that these two types of controls are correlated across countries.

\section{REFERENCES}

Aghion, P., \& Howitt, P. (1998). Endogenous growth theory. Cambridge, MA: MIT Press.

Alesina, A., \& Spoalare, E. (1997). On the number and size of nations. Quarterly Journal of Economics, November.

Alesina, A., Baqir, R., \& Easterly, W. (1999). Public goods and ethnic divisions. Quarterly Journal of Economics, forthcoming.

Armstrong, H., de Kervenoael, R. J., Li, X., \& Read, R. (1998). A comparison of the economic performance of different microstates and between microstates and larger countries. World Development, 26(4), 639-656.

Armstrong, H. W., \& Read, R. (1998). Trade and growth in small states: the impact of global trade liberalization. World Economy.

Barro, R., \& Sala-I-Martin, X. (1995). Economic growth. New York: McGraw-Hill.

Benedict, B. (1967). Problems of smaller territories. London: Athlone Press.

Briguglio, L. (1995). Small island developing states and their economic vulnerabilities. World Development, 23(9), 1615-1632.

Cashin, P., \& Loayza, N. (1995). Paradise lost? Growth, convergence, and migration in the South Pacific. IMF Staff Papers, 42, 608-641.

Commonwealth Consultative Group (1985). Vulnerability: Small states in the global society. London: Commonwealth Secretariat.

Commonwealth Consultative Group (1997). A future for small states: Overcoming vulnerability. London: Commonwealth Secretariat.

Dobozi, I., Keller, C., \& Matejka, H. (1982). Small countries and international structural adjustment: a collection of Hungarian and Swiss views. In I. Dobozi, C. Keller, \& H. Matejka (Eds.), Proceedings of the second Hungarian-Swiss Round Table, 7-11 April 1981. Geneva: study Group on East-West Relations, Graduate Institute of International Studies

Dolman, A. (1985). Paradise lost? The past performance and future prospects of small island states. In
E. Dommen, P. Hein (Eds.), States, microstates and islands, London: Croom Helm.

Doumenge, F. (1983). Viability of small island states. Paper prepared for United Nations Conference on Trade and Development.

Easterly, W., \& Levine, R. (1997). Africa's growth tragedy: policies and ethnic divisions. Quarterly Journal of Economics, November.

Easterly, W., \& Rebelo, S. (1993). Fiscal policy and economic growth: an empirical investigation. Journal of Monetary Economics, 32, 417-457.

Farrugia, C. (1993). The special working environment of senior administrators in small states. World development, 21(2), 221-226.

Grilli, V., \& Milesi-Ferretti, G. M. (1995). Economic effects and structural determinants of capital controls. International Monetary Fund Staff Papers, 42(3), 517-551.

Harden, S. (1985). Small is dangerous: Micro states in a macro world. London: Frances Pinter.

International Monetary Fund (IMF) (various issues). Annual report on exchange arrangements and exchange restrictions. Washington DC: IMF.

Kaminarides, J., Briguglio, L., \& Hoogendonk, H. N. (1989). The economic development of small countries problems strategies and policies. Delft: Eburon.

Kraay, A. (1998). In Search of the macroeconomic effects of capital account liberalization. Manuscript, Washington DC: World Bank.

Kraay, A., \& Ventura, J. (1998). Comparative advantage and the cross-section of business cycles. World Bank Policy Research Department Working Paper No. 1948. Washington, DC: World Bank.

Kuznets, S. (1960). Economic growth of small nations. In E. A. G. Robinson (Ed.). The economic consequences of the size of nations, Proceedings of a conference held by the international economic associations. Toronto: MacMillan.

Lewis, K. (1996). What can explain the apparent lack of international consumption risk sharing? Journal of Political Economy, 104, 267-297. 
Mankiw, N. G., Romer, D., \& Weil, D. (1992). A contribution to the empirics of economic growth. Quarterly Journal of Economics.

Milner, C., \& Westaway, T. (1993). Country size and the medium-term growth process: some cross-country evidence. World Development, 21(2), 203-211.

Ramey, G., \& Ramey, V. A. (1995). Cross-country evidence on the link between volatility and growth. American Economic Review, 85, 1138-1151.

Robinson, E. A. G. (1960). The economic consequences of the size of nations: Proceedings of a conference held by the international economic associations. Toronto: MacMillan.

Rodrik, D. (1998). Who needs capital account convertibility? In P. Kenen (Ed.). Should the IMF pursue capital-account convertibility? Princeton Essays in International Finance, No. 207.

Romer, P. M. (1986). Increasing returns and long-run growth. Journal of Political Economy, 94, 10021037.

Scitovsky, T. (1960). International trade and economic integration as a means of overcoming the disadvantages of a small nation. In E. A. G. Robinson (Ed.). The economic consequences of the size of nations, Proceedings of a conference held by the international economic associations. Toronto: MacMillan.

Small States Financial Forum (1987). Round table on foreign investment and commercial finance for small states. London: Crown Agents Financial Advisory Service.

Small States Financial Forum (1988). Round table on some practical possibilities of financial co-operation between small states. London: Crown Agents Financial Advisory Service.

Srinivasan, T. N. (1986). The costs and benefits of being a small remote island landlocked or ministate economy. World Bank Research Observer, 1(2), 205-218.

Streeten, P. (1993). The special problems of small countries. World Development, 21(2), 197-202.

Tarshis, L. (1960). The size of the economy and its relation to stability and steady progress. In E. A. G. Robinson, The economic consequences of the size of nations, Proceedings of a conference held by the international economic associations. Toronto: MacMillan.
United Nations Institute for Training and Research (1971). Small states and territories: Status and problems. New York: Arno Press.

UNCTAD (1997). The vulnerability of small island developing states in the context of globalisation. Geneva: UNCTAD.

\section{APPENDIX A. VARIABLE DEFINITIONS AND DATA SOURCES}

This appendix documents the definitions of all variables and the data sources from which they were constructed. Variables are listed in the order in which they appear in Table 8. The sample consists of all countries for which at least 10 years of data on real per capita GDP adjusted for purchasing power parity are available, as documented below. Since a number of very small states do not report national accounts data and/or are not included in the United Nations/World Bank Income Comparison Project, real per capita GDP data are not available for these states. As discussed in the text, it is not clear a priori what sorts of biases this might introduce. Nevertheless, some caution is in order before extending the results to the universe of small states.

All of the cross-sectional regressions are based on averages over all available years of the relevant variables. As a result, the time period covered for each country varies with the length of the time series available for that country. Due to unavailability of additional explanatory variables, the sample of countries covered in the regressions varies, ranging from the maximum possible of 157 to a minimum of 114 .

(For Table 8 see opposite). 
Table 8. Variable definitions and data sources

\begin{tabular}{|c|c|c|}
\hline Variable name & Comments & Source \\
\hline Small state & $\begin{array}{l}\text { Indicator variable for average population over all available years } \\
1960-95 \text { less than one million }\end{array}$ & $\begin{array}{l}\text { World Bank } \\
\text { World Table }\end{array}$ \\
\hline OECD member & $\begin{array}{l}\text { Indicator variable for } 24 \text { members of OECD before recent } \\
\text { expansions }\end{array}$ & \\
\hline Oil exporter & Fuel (SITC3) exports account for more than $50 \%$ of total exports & $\begin{array}{l}\text { World Bank } \\
\text { World Develop- } \\
\text { ment Report } 1996\end{array}$ \\
\hline $\begin{array}{l}\text { Real GDP per } \\
\text { capita }\end{array}$ & $\begin{array}{l}\text { Primary source is the Summers and Heston Penn World Table, } \\
\text { Version 5.6, measured in } 1985 \text { international dollars. Missing } \\
\text { observations in the PWT are filled in where possible using } \\
\text { PPP-adjusted GDP estimates reported by the World Bank. }\end{array}$ & $\begin{array}{l}\text { Summers and } \\
\text { Heston, World } \\
\text { Bank World } \\
\text { Tables }\end{array}$ \\
\hline Infant mortality & Infant mortality per thousand live births. & $\begin{array}{l}\text { World Bank } \\
\text { World Tables }\end{array}$ \\
\hline Life expectancy & Life expectancy at birth, measured in years & $\begin{array}{l}\text { World Bank } \\
\text { World Tables }\end{array}$ \\
\hline Investment/GDP & $\begin{array}{l}\text { Ratio of investment to GDP adjusted for purchasing power } \\
\text { parity. Available only for countries appearing in Summers and } \\
\text { Heston since World Bank does not report PPP GDP by } \\
\text { expenditure components }\end{array}$ & $\begin{array}{l}\text { Summers and } \\
\text { Heston }\end{array}$ \\
\hline $\begin{array}{l}\text { Initial real per } \\
\text { capita GDP }\end{array}$ & Real per capita GDP in the first available year for that country & $\begin{array}{l}\text { Summers and } \\
\text { Heston, World } \\
\text { Bank World } \\
\text { Tables }\end{array}$ \\
\hline $\begin{array}{l}\text { Secondary school } \\
\text { enrollment rates }\end{array}$ & Gross secondary school enrollment rates, percent & $\begin{array}{l}\text { World Bank } \\
\text { World Tables }\end{array}$ \\
\hline $\begin{array}{l}\text { Share of trade in } \\
\text { GDP }\end{array}$ & $\begin{array}{l}\text { Exports plus imports as a share of GDP, both measured in } \\
\text { constant-price local currency units }\end{array}$ & $\begin{array}{l}\text { World Bank } \\
\text { World Tables }\end{array}$ \\
\hline $\begin{array}{l}\text { Terms of trade } \\
\text { growth }\end{array}$ & $\begin{array}{l}\text { Growth rate of local currency export deflator multiplied by share } \\
\text { of exports in GDP, less growth rate of local currency import } \\
\text { deflator multiplied by share of imports in GDP }\end{array}$ & $\begin{array}{l}\text { World Bank } \\
\text { World Tables }\end{array}$ \\
\hline $\begin{array}{l}\text { Unweighted terms } \\
\text { of trade growth }\end{array}$ & $\begin{array}{l}\text { Growth rate of local currency export deflator less growth rate of } \\
\text { local currency import deflator }\end{array}$ & $\begin{array}{l}\text { World Bank } \\
\text { World Tables }\end{array}$ \\
\hline $\begin{array}{l}\text { OECD average } \\
\text { growth }\end{array}$ & $\begin{array}{l}\text { Population-weighted average of real per capita GDP growth } \\
\text { rates of } 24 \text { OECD member countries before recent expansions }\end{array}$ & $\begin{array}{l}\text { Summers and } \\
\text { Heston, World } \\
\text { Bank World } \\
\text { Tables }\end{array}$ \\
\hline Capital controls & $\begin{array}{l}\text { Average over all available years of indicator variable for presence } \\
\text { of restrictions on capital account transactions }\end{array}$ & $\begin{array}{l}\text { International } \\
\text { Monetary Fund } \\
\text { Annual Report } \\
\text { on Exchange } \\
\text { Arrangements } \\
\text { and Exchange } \\
\text { Controls }\end{array}$ \\
\hline $\begin{array}{l}\text { Capital inflows } \\
\text { and outflows as } \\
\text { share of GDP }\end{array}$ & $\begin{array}{l}\text { Sum of credit items plus }-1 \text { times debit items in the financial } \\
\text { account of the balance of payments, expressed as a share of GDP } \\
\text { in current dollars at market exchange rates }\end{array}$ & $\begin{array}{l}\text { International } \\
\text { Monetary Fund } \\
\text { Balance of Pay- } \\
\text { ments Statistics } \\
\text { Yearbook } \\
\text { Revision } 5\end{array}$ \\
\hline
\end{tabular}

